\title{
Reduction in Incidence of Ampicillin Rash by Purification of Ampicillin
}

\author{
E. T. KNUDSEN, ${ }^{*}$ M.B., B.S., F.R.C.PATH. ; JANET M. DEWDNEY, $†$ B.v.SC., M.R.C.v.s. ; \\ J. A. P. TRAFFORD, $\ddagger$ M.D., M.R.C.P.
}

$S^{-}$ mmary: Purification of ampicillin (Penbritin) with respect to protein impurities has been found significantly to reduce the incidence of rashes in treated patients. This may be related to findings in animals that injections of the isolated protein impurity can induce the formation of circulating IgG antibodies and skinsensitizing antibodies.

\section{Introduction}

Recent publications (Batchelor, Dewdney, Feinberg, and Weston, 1967; Stewart, 1967; Knudsen, Robinson, Croydon, and Tees, 1967) have shown that commercially available benzylpenicillin contains varying trace amounts of a penicilloylated protein impurity. 6-Aminopenicillanic acid (6-APA), the "nucleus" from which all of the semisynthetic penicillins are prepared, has also been shown to contain a similar material (Batchelor et al., 1967; Stewart, 1967) which may be derived from benzylpenicillin or from the Escherichia coli enzyme preparation used to remove the phenyl acetyl side-chain in the production process. Animal and human tests have shown this impurity to be both powerfully immunogenic and allergenic (Batchelor et al., 1967; Stewart, 1967). The presence of this impurity in 6-APA immediately raised the question of how much finds its way into the final semisynthetic penicillin, particularly the amphoteric ampicillin.

Ampicillin (Penbritin) was introduced to the medical profession in 1961 and has become by far the most widely used semisynthetic penicillin. Since then there have been a number of reports of skin eruptions associated with the oral administration of this penicillin, the incidence of which has varied from as much as $20 \%$, associated with high-dosage treatment of salmonella infections, to less than $2 \%$ associated with the treatment of other conditions.

On the whole the rash has been described as presenting in two main forms-firstly, an urticarial type, which probably represents true penicillin hypersensitivity, and, secondly, an irritant erythematous "morbilliform" or maculopapular type which may often disappear if the course of treatment is continued with or without the administration of antihistamines. The rash may present during the first few days of treatment or sometimes appear as long as five days after treatment has been discontinued, the so-called "fifth-day rash" (Stevenson and Mandal, 1966).

It is not known whether the latter type of rash has an immunological or allergic origin, and its relationship, if any, to reaginic antibody induced penicillin allergy is not known.

Immunological and clinical work is reported which investi-

\footnotetext{
* Medical Director, Beecham Research Laboratories, Brentford, Middlesex. t Head of Immunochemistry Department, Beecham Research Laboratories, Brockham Park, Betchworth, Surrey.

$\ddagger$ Consultant Physician, Brighton and Lewes Hospital Group.
}

gates the importance of high molecular weight protein impurity in commercial ampicillin in relation to the immunogenicity of ampicillin in rabbits, skin-sensitizing antibody and rash induction in baboons, and the incidence of rashes in patients treated with ampicillin.

\section{Immunological Experiments}

It has been reported previously that standard 6-APA produces high levels of penicilloyl-specific antibodies but that after purification processes to remove high molecular weight impurities 6-APA failed to induce these levels of antibodies in rabbits (Batchelor et al., 1967).

A similar situation applies to ampicillin. Ampicillin prepared from original process 6-APA when injected into rabbits by the immunization schedule given in Table I stimulates high levels of penicilloyl specific antibody (samples 4298, 4297, and 4260), but when ampicillin is prepared from 6-APA specially purified by complex adsorption processes to remove protein impurities (Munden, 1965) lower levels of antibody are induced (samples 4295, 4296, and 4294).

Further evidence that it is the protein impurity influencing and enhancing the immunogenicity is provided by purifying ampicillin itself. If an ampicillin sample that has been shown to induce high antibody levels in rabbits is itself subjected to the purification process as above, antibody stimulated by the purified ampicillin is reduced to a negligible level (samples N103, N104, and N102).

It is clear, therefore, that ampicillin as produced by us at that time could be highly immunogenic, and it was found that it was not unique in this respect. Immunization studies with other commercially available ampicillins have shown a similar range of haemagglutination titres.

The considerations which apply to the immunogenicity of penicillins in rabbits may not be the same as those that relate to the various manifestations of allergy in patients, but the lowering of immunogenicity obtained with purified forms of ampicillin is interesting enough for us to believe that the removal of protein from penicillin will lead to a lower incidence of hypersensitivity in patients receiving the drug therapeutically. Encouragement for this view comes from experiments carried out in baboons. In as yet unpublished experiments it has been demonstrated that the injection of the isolated protein impurity derived from ampicillin can induce not only circulating IgG antibodies but also skin-sensitizing antibodies which can be detected by the weal and erythema responses that develop on injection of the protein into the skin. To this extent these baboons are equivalent to those patients with clinical penicillin hypersensitivity who give weal and erythema reactions on skin testing. Moreover, in the course of these experiments a maculopapular rash developed in some of the baboons. The rash ran a protracted course, was non-pruritic, and the distribution was over the ventral aspects of the body in the axilla and inguinal 
regions and around the muzzle. As is often found in patients the weal and erythema response was absent for the duration of the rash, probably due to a peripheral defect, an inability of the skin to respond to challenge.

These results in a primate species strongly suggest that the protein impurity plays a significant part in the development of rashes in patients receiving penicillin therapy, and a pilot clinical trial was set up, designed to see whether the incidence of rashes was significantly reduced in patients receiving purified ampicillin.

The results of this clinical trial are presented below. As a consequence of the introduction of an improved production process and control procedures to monitor levels of protein impurity in every batch of 6-APA, it has now been possible to produce ampicillin of the quality used in this pilot trial on a production scale (Table I)

TABLE I.-Immunogenicity in Rabbits of Three Samples of Ampicillin Before and After Purification and Three Samples of Ampicillin Prepared from Purified 6-APA

\begin{tabular}{|c|c|c|c|c|c|}
\hline \multirow[t]{3}{*}{$\begin{array}{l}\text { Ampicillin } \\
\text { Batch No. }\end{array}$} & \multirow[t]{3}{*}{ Method of Purification } & \multirow{2}{*}{\multicolumn{4}{|c|}{$\begin{array}{l}\text { Antibody induced in } 3 \\
\text { rabbits. Titre expressed as } \\
\text { mean } \log _{2} \text { of reciprocal of } \\
\text { highest dilution showing } \\
\text { haemagglutination }\end{array}$}} \\
\hline & & & & & \\
\hline & & 8 & 15 & 22 & 29 \\
\hline N103 & $\begin{array}{l}\text { None, from original process unpurified } \\
\text { 6-APA } \\
\text { Adsorption purification of ampicillin } \\
\text { batch } 4298\end{array}$ & $\begin{array}{c}2 \cdot 6 \\
0\end{array}$ & $\begin{array}{c}2 \cdot 3 \\
1\end{array}$ & $\begin{array}{c}7 \\
1 \cdot 3\end{array}$ & $1 \cdot 3$ \\
\hline N104 & $\begin{array}{l}\text { None, from original process unpurified } \\
\text {-APA } \\
\text { Adsorption purification of ampicillin } \\
\text { batch } 4297\end{array}$ & $6 \cdot 3$ & $9 \cdot 6$ & $9 \cdot 3$ & 9 \\
\hline $\begin{array}{l}4260 \\
\mathrm{~N} 102\end{array}$ & $\begin{array}{l}\text { None, from original process unpurified } \\
\text { 6-APA } \\
\text { Adsorption purification of ampicillin } \\
\text { batch } 4260\end{array}$ & $1 \cdot 6$ & $1 \cdot 6$ & $7 \cdot 6$ & 7 \\
\hline $\begin{array}{l}4295 \\
4296 \\
4294\end{array}$ & $\begin{array}{l}\text { Ampicillins prepared from original pro- } \\
\text { cess 6-APA, purified by adsorption, } \\
\text { before ampicillin production }\end{array}$ & $\begin{array}{l}0 \\
0 \\
1\end{array}$ & $\begin{array}{c}0 \\
0 \\
1 \cdot 6\end{array}$ & $\begin{array}{c}1 \\
1 \\
4 \cdot 3\end{array}$ & $\begin{array}{l}2 \cdot 6 \\
4 \\
4 \cdot 6\end{array}$ \\
\hline $\begin{array}{c}\text { Mean of } 14 \\
\text { batches }\end{array}$ & $\begin{array}{l}\text { Routine production ampicillins pre- } \\
\text { pared according to new controlled } \\
\text { factory process }\end{array}$ & 0 & 0 & $1 \cdot 1$ & $2 \cdot 2$ \\
\hline
\end{tabular}

Immunization Schedule: The ampicillin samples were prepared as suspensions in $0.15 \mathrm{M} \mathrm{NaC1}$, emulsified in Freund's complete adjuvant and injected subcutaneously into three rabbits at a dose of $50 \mathrm{mg}$. on Days 1,8 , and 15 . cutaneously into three rabbits at a dose of $50 \mathrm{mg}$. On Days 1,8 , and 15 .
Additionally, $1 \mathrm{mg}$. of ampicillin in $1 \%$ methyl cellulose was given in six intradermal sites on Day 1 . The antisera were tested against benzylpenicilloylated erythrocytes (Thiel, Mitchell, and Parker, 1964).

A multicentre clinical trial is now in progress using ampicillin prepared from this 6-APA, and the results to date are confirming a significant reduction in the incidence of rashes.

\section{Patients Studied}

Design of Clinical Trial.-Two types of ampicillin were encapsulated in the standard red and black capsules (Penbritin): (1) ampicillin type A (made from purified 6-APA as described above) and (2) ampicillin type $B$ (the then commercially available material). A double-blind clinical trial was initiated at the Royal Sussex Hospital, the Brighton General Hospital, and the Hove General Hospital, representing some 1,000 beds. For the first three months all patients who were prescribed ampicillin received type A (purified) material and the number of patients treated and the number and type of rash were noted. For the next three months type $B$ ampicillin was used and again the number of patients treated and the numbers and types of rash were noted. At the end of this period the hospitals reverted to type A for a further three months and alternated every three months for some 18 months. This was an administratively more practical method of conducting the trial at three hospitals than attempting to treat alternate patients with type $A$ and type $B$ ampicillin. Ampicillin was withdrawn from all patients who developed a rash. On leaving hospital the patients were told to report on their return as outpatients any side-effects that might arise after their discharge.

Number of Patients Taking Part.-At the end of the 18month period 1,068 patients had been treated with type $\mathrm{A}$ and 1,077 with ampicillin type $B$.

Dosage.-The dosage was equally divided between both groups of patients and was always oral and never greater than $500 \mathrm{mg}$. four times a day. Most patients were treated at a dosage of $250 \mathrm{mg}$. four times a day.

Infections Treated.-With the exception of one case of septicaemia with renal failure and one case of suspected meningitis, all other infections were those of either the urinary or the respiratory tract.

Description of Rash.-It will readily be appreciated that the terminology of the description of rashes in three different hospitals might well vary, but care was taken to distinguish quite clearly between urticarial rashes and those of the morbilliform type.

\section{Results}

Incidence of Rashes (Type A and Type B).-Table II shows the incidence of rashes. Of the 1,068 patients treated with type

TABLE II.-Summary of Incidence of Rashes to Type A and Type B Ampicillin

\begin{tabular}{|c|c|c|c|c|c|c|c|}
\hline \multicolumn{2}{|c|}{$\begin{array}{c}\text { No. of } \\
\text { patients treated }\end{array}$} & \multicolumn{3}{|c|}{$\begin{array}{l}\text { Description and number of } \\
\text { rashes }\end{array}$} & \multicolumn{3}{|c|}{ Infections treated } \\
\hline $\begin{array}{c}\text { Type } \\
\text { A }\end{array}$ & Type & & $\underset{\text { A }}{\text { Type }}$ & $\underset{B}{\text { Type }}$ & & Type & Type \\
\hline 1,068 & 1,077 & $\begin{array}{l}\text { Erythematous } \\
\text { Morbilliform } \\
\text { Maculopapular } \\
\text { Erythematous and } \\
\text { maculopapular } \\
\text { Urticarial } \\
\text { Macular } \\
\text { Eczema }\end{array}$ & $\begin{array}{l}4 \\
4 \\
3 \\
2 \\
1 \\
1\end{array}$ & $\begin{array}{r}10 \\
3 \\
16 \\
3 \\
1 \\
1\end{array}$ & $\begin{array}{l}\text { Respiratory } \\
\text { Urinary } \\
\text { Meningeal } \\
\text { Septicaemia }\end{array}$ & $\begin{array}{l}6 \\
8 \\
1\end{array}$ & $\begin{array}{r}12 \\
20 \\
1\end{array}$ \\
\hline 1,068 & 1,077 & & 15 & 33 & & 15 & 33 \\
\hline
\end{tabular}

Incidence of rashes to type $\mathrm{A}$ material $=1.4 \%$. Incidence of rashes to type $\mathrm{B}$ material $=3.1 \% \cdot \chi^{2}=6.01, \mathrm{P}<0.02$.

A, 15 developed a rash, an incidence of $1.4 \%$. Subsequently one of the patients developing a rash in this group was found to have previously been hypersensitive to penicillin. Of the 1,077 patients treated with type $B$ material, 33 developed a rash, an incidence of $3.1 \%$. The results show a statistically significant difference in the incidence of rashes in patients treated with type $A$ and type $B$ ampicillin. The mean interval between start of treatment and appearance of rash was three days.

\section{Discussion}

The reported incidence of ampicillin rashes varies with the source of the information. In a trial of oral ampicillin in acute gonorrhoea (Willcox, 1963) one patient out of 175 followed for seven days developed a slight urticaria (approximately $0.6 \%$ ), though only a one-dose or two-dose treatment was used. In a recent study (Cuellar and Puente, 1967) of oral ampicillin in the treatment of 90 patients with infections of the genitourinary tract, one rash was experienced $(1.1 \%)$. On the other hand, a very high incidence of rashes has tended to be associated with the treatment of salmonella infections using a dosage of 4-8 g./day. For example, 18 cutaneous reactions were noted in 88 paratyphoid fever patients (approximately 20.5\%) (Sleet, Sangster, and Murdoch, 1964), and there were 39 rashes in 198 typhoid fever patients (19.7\%) (Walker, 1965). Shapiro, Slone, Siskind, Lewis, and Jick (1969) found an incidence of $9.5 \%$ of 422 patients treated. The highest reported incidence of 
rashes to ampicillin was associated with its administration to patients with glandular fever (18 out of 19 patients $=95 \%$ ) (Pullen, Wright, and Murdoch, 1967).

Because of the uncertainty about the true incidence of cutaneous reactions to ampicillin, it was considered of interest to carry out a complete survey of the published clinical literature (Lynn, 1969). It was found that ampicillin treatment had been described in a total of 13,638 patients up to 1 March 1969, and it was reported that 384 subjects had experienced skin reactions of one kind or another-an incidence of $2.8 \%$. The reported skin reactions may be classified as shown in Table III.

TABLE III.-Incidence of Various Types of Skin Reaction Reported During Ampicillin Therapy (Lynn, 1969)

\begin{tabular}{|c|c|c|c|c|c|}
\hline \multicolumn{3}{|l|}{ Type of Rash } & $\begin{array}{c}\begin{array}{c}\text { No. } \\
\text { reported }\end{array} \\
60 \\
23 \\
10\end{array}$ & $\begin{array}{c}\begin{array}{c}\% \text { of total } \\
\text { patients } \\
\text { treated }\end{array} \\
0.44 \\
0 \cdot 17 \\
0.07 \\
\end{array}$ & $\begin{array}{c}\begin{array}{c}\% \text { of total } \\
\text { skin } \\
\text { reactions }\end{array} \\
\begin{array}{c}15 \cdot 6 \\
6 \cdot 0 \\
2 \cdot 6\end{array}\end{array}$ \\
\hline 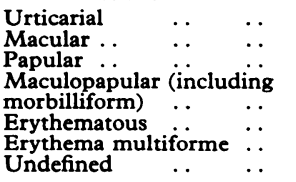 & $\begin{array}{l}\cdots \\
\cdots \\
\cdots \\
\cdots \\
\cdots\end{array}$ & $\begin{array}{l}\cdots \\
\cdots \\
\cdots \\
\cdots \\
\cdots\end{array}$ & $\begin{array}{r}60 \\
23 \\
10 \\
114 \\
7 \\
1 \\
169\end{array}$ & $\begin{array}{l}0.44 \\
0.17 \\
0.07 \\
0.83 \\
0.05 \\
0.01 \\
1.24\end{array}$ & $\begin{array}{r}15 \cdot 6 \\
6 \cdot 0 \\
2 \cdot 6 \\
29 \cdot 7 \\
1 \cdot 8 \\
0 \cdot 3 \\
44 \cdot 0\end{array}$ \\
\hline & & & 384 & $2 \cdot 81$ & \\
\hline
\end{tabular}

An incidence of $3.1 \%$ with type B would appear to be consistent with that determined from the above survey of the international literature. Consideration of the type of infection associated with the higher incidence of rashes might suggest that the use of ampicillin for the treatment of conditions that in themselves are often associated with a rash (typhoid and paratyphoid fever, glandular fever, etc.) tends to increase the overall incidence of skin eruptions. In view of the bactericidal action of ampicillin, a rash might also be associated with rapid lysis of intestinal organisms giving rise to skin-sensitizing "agents." The results of this study, however, suggest that one of the factors involved is the presence of penicilloyl protein impurity. As the material is also responsible for the induction of antibodies in experimental animals and, in particular, of skin-sensitizing antibodies in a primate species, it is tempting to speculate that the rash may have an underlying allergic or immunological mechanism. It may be significant that the most dramatic effect seen in this trial was the reduction in maculopapular rashes in patients treated with purified ampicillin. This was the type of rash described in baboons, and further studies in this species may shed light on the aetiology of this condition and its relation to the presence or absence of skin-sensitizing antibodies. Further clinical studies have been instituted to obtain comprehensive data on the possible mode of action of the impurity, dosage dependence, signs of generalized systemic hypersensitivity, and relation of the type of rash to conventional penicillin allergy and future penicillin treatment of the patient.

Meanwhile, the recognition of impurities and the introduction of control procedures to eliminate them results in ampicillin of increased and controlled purity, and it is expected that this increased purity will lead to a reduction in the numbers of adverse reactions to ampicillin, whether these are of allergic or of immunological aetiology. Beecham Research Laboratories have instituted the controlled procedures outlined above for 6-APA, and all Penbritin (ampicillin) currently made by them should have a lower rash potential.

REFERENCES

Batchelor, F. R., Dewdney,, Janet, M., Feinberg, J. G., and Weston, R. D. (1967). Lancet, 1, 1175.

Cuellar, G., and Puente, R. (1967). Current Therapeutic Research, 9,

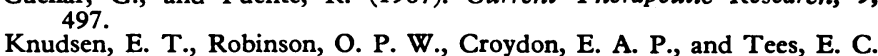
(1967). Lancet, 1, 1184.

Lynn, B. (1969). Beecham Research Laboratories Medical Records.

Personal communication.
Munden, J. (1965) British Patent Application No. 48995/65.

Pullen, H., Wright, N., and Murdoch, J. McC. (1967). Lancet, 2, 117.6.

Shapiro, S., Slone, D., Siskind, V., Lewis, G. P., and Jick, H. (1969) Lancet, 2, 969.

Sleet, R. A., Sangster, G., and Murdoch, J. McC. (1964). British Medical fournal, 1, 148.

Stevenson, J., and Mandal, B. (1966). British Medical fournal, 1, 1359.

Stewart, G. T. (1967). Lancet, 1, 1177.

Thiel, J. A., Mitchell, Shirley, and Parker, C. W. (1964). fournal of Allergy, 35, 399.

Walker, W. (1965). Scottish Medical fournal, 10, 466.

Willcox, R. R. (1963). British fournal of Venereal Diseases, 39, 164.

\title{
Controlled Trial of Propranolol in Hypertension
}

\author{
F. J. ZACHARIAS, ${ }^{*}$ M.D., F.R.C.P.; K. J. COWEN, $†$ м.B., в.CH.
}

$S^{u}$ mmary: A trial of oral propranolol as a hypotensive agent was designed to provide adequate treatment periods. Twenty-eight patients with essential hypertension, with a mean blood pressure of $190 / 111 \mathrm{~mm}$. $\mathrm{Hg}$, were controlled on $120-320 \mathrm{mg}$. of propranolol daily. Their mean treated blood pressure was 153/91. They then entered, on a randomized and double-blind basis, a cross-over trial of two 16-week periods, blood pressure being measured fortnightly. Propranolol caused a statistically significant fall in blood pressure when compared with placebo. When propranolol was withdrawn blood pressures rapidly rose to hypertensive levels, though not to untreated levels. No postural hypotension was found, but a small change in blood pressure levels on exercise was noted.

\footnotetext{
* Consultant Physician.

† General Practitioner and Clinical Assistant, Hypertension Unit, Clatterbridge General Hospital, Wirral, Cheshire.
}

The first report that a beta-adrenergic antagonist, when given orally to hypertensive subjects, would reduce blood pressure came in 1964 and followed work with pronethalol (Prichard, 1964). When pronethalol was replaced by propranolol there followed several reports of its oral use in hypertension. These reports may be divided into two groups. In the first group propranolol was given in an open and uncontrolled mannerthat is, not double-blind. The results seemed to indicate modest benefit with relatively small doses (Waal, 1966; Richards, 1966; Gebhardt et al., 1967) and appreciable hypotensive action with slightly larger doses (Frohlich et al., 1968; Tewari and Grant, 1968). Prichard and Gillam (1966, 1969), with greater flexibility of dosage, concluded that propranolol is an effective hypotensive drug, comparable in potency to guanethidine, bethanidine, or methyldopa.

In the second group propranolol was given in clinical trials having either a cross-over design (Paterson and Dollery, 1966) 